\title{
Aplikasi Pupuk Organik Cair Menggunakan Bioaktivator Mikroorganisme Indigenous HPPB Untuk Pertumbuhan Desmodium heterophyllum pada Tanah Bekas Tambang Batu Kapur PT. Semen Padang
}

\section{(Application of Liquid Organic Fertilizers by Using Indigenous Microorganism Bioactivator Of HPPB For Growth of Desmodium heterophyllum on Limestone Mined Land At PT. Semen Padang)}

\author{
Rizqa Zidna Chairafahmi ${ }^{*}$, Suwirmen dan Zozy Aneloi Noli
}

Laboratorium Fisiologi Tumbuhan, Jurusan Biologi, FMIPA, Universitas Andalas, Padang, Sumatera Barat 25163

${ }^{*}$ Koresponden : rizurizqa@gmail.com

\begin{abstract}
The research about application of liquid organic fertilizers with indigenous microorganism bioactivator of HPPB for growth of Desmodium heterophyllum on limestone mined land at PT. Semen Padang, had been conducted from May to August 2015 in Nursery and Reforestation, Laboratory of Plant Physiology Department of Biology, and the Laboratory of Soil Science Faculty of Agriculture, Andalas University, Padang. The research aimed to determine the effect and concentration of Liquid Organic Fertilizers (LOF) by using indigenous microorganism bioactivator originated from HPPB in limestone mined land ofPT. Semen Padang. This study used Completely Randomized Design (CRD) with five treatments and four replications. The treatments were control without LOF (A), 10\% LOF (B), 20\% LOF (C), 30\% LOF (D) and 40\% LOF (E). The results showed that $10 \%$ LOF was the best concentration to increase the number of leaves $(36,44)$, percentage of land cover $(6,71 \%)$ and fresh weight of plants $(5,15 \mathrm{~g})$.
\end{abstract}

Keywords : Desmodium heterophyllum, indigenous microorganisms, limestone mined land, liquid organic fertilizers

\section{Pendahuluan}

Desmodium heterophyllum adalah salah satu tanaman "fast growing species (FGS)" yang termasuk kedalam famili Leguminoceae (Ardanari, 2011). Tanaman ini juga merupakan salah satu tanaman penutup lahan (cover crop) yang berperan dalam mengurangi kekuatan dispersi air hujan dan kecepatan aliran air permukaan sehingga dapat mengurangi terjadinya erosi (De Lima, Ezequiel, Luis, Eloy dan Alvaro, 2012). Selain itu tanaman ini mampu memanfaatkan $\mathrm{N}_{2}$ di udara, dan bahan organik yang dihasilkan tanaman ini kaya akan unsur hara N (Ardika, 2013). Kondisi seperti ini akan mampu mempercepat pemulihan kesuburan tanah (Ardika, 2013). Tanaman ini mudah diperbanyak, pertumbuhannya cepat, mampu beradaptasi dilahan yang kering dan memiliki kemampuan yang cepat dalam menutup tanah (Mansur dan Ariani, 2013), untuk pengendalian gulma, dapat mengurangi perkecambahan dan perkembangan biji gulma (Ohno, 2000 dalam Hasanah, Wasis, Mansur, 2013). Oleh karena itu tanaman ini dapat dijadikan sebagai salah satu tanaman alternatif dalam upaya reklamasi lahan bekas kegiatan pertambangan.

Penelitian sebelumnya tentang penggunaan Legume Cover Crop sebagai upaya perbaikan lahan bekas tambang telah banyak dilakukan diantaranya penelitian yang dilakukan oleh Hasanah et al., (2013). Upaya rehabilitasi lahan bekas tambang batu bara yang menggunakan tiga jenis tanaman Desmodium, menunjukkan bahwa jenis Desmodium heterophyllum memiliki kecepatan penutupan lahan pada waktu 8 MST mencapai $100 \%$ dibandingkan jenis D. ovalifolium dan D. triflorum. 
$\begin{array}{rrr}\text { Pada penelitian ini untuk } \\ \text { meningkatkanpertumbuhan } & & D .\end{array}$ heterophyllum pada lahan bekas tambang batu kapur dapat ditambahkan pupuk organik cair (POC) dengan bioaktivator mikroorganisme indigenous (mikroorganisme lokal) sebagai salah satu input unsur haranya. Pupuk organik cair mengandung berbagai jenis unsur hara makro dan mikro berupa mineral, asam amino, hormon pertumbuhan dan mikroorganisme (Parnata, 2004). Pemanfaatan mikroorganisme indigenous sebagai bioaktivator dikarenakan manfaatnya sebagai perombak bahan organik, perangsang pertumbuhan dan agen pengendali penyakit maupun hama tanaman (Untung, 2014 dalam Hajama, 2014). Pada penelitian ini mikroorganisme indigenous yang digunakan berasal dari Hutan Pendidikan dan Penelitian Biologi (HPPB) Universitas Andalas (UNAND). HPPB UNAND termasuk salah satu hutan hujan tropis yang dengan alami memiliki udara lembab dan humus tebal yang diduga banyak mengandung mikroorganisme tanah (Wulandari, 2011).

Lahan bekas kegiatan pertambangan yang digunakan pada penelitian ini yaitu tambang batu kapur milik PT Semen Padang yang ada di Sumatera Barat. Mufhendris (2005) menyatakan berdasarkan Studi Evaluasi Lingkungan (SEL) PT Semen Padang oleh Departemen Perindustrian, didapati tanah terbuka tanpa vegetasi seluas $67 \mathrm{Ha}$.

Kerusakan lingkungan akibat kegiatan pertambangan tersebut dapat dilihat dari faktor fisika, kimia dan biologi. Secara fisika proses penambangan tersebut mengakibatkan tanah tidak berprofil, rusaknya struktur, tekstur, porositas dan terjadinya bulk density tanah. Secara kimia menyebabkan rendah nya $\mathrm{pH}$ dan kekurangan unsur-unsur hara di dalam tanah dan dari segi biologi menyebabkan kerusakan yang signifikan terutama kerusakan pada lapisan tanah atas (top soil) yang memiliki banyak unsur hara. Kondisi ini menyebabkan vegetasi tanaman sulit bahkan tidak mampu tumbuh di areal bekas pertambangan karena tidak terpenuhinya unsur-unsur yang mendukung pertumbuhan tanaman (Margarettha, 2009).

Tujuan dari penelitian ini yaitu untuk mengetahui pengaruh pemberian dan untuk mengetahui konsentrasi pupuk organik cair dengan bioaktivator mikroorganisme indigenous pada pertumbuhan $D$. heterophyllum pada tanah lahan bekas tambang batu kapur PT. Semen Padang.

\section{Metode Penelitian}

Penelitian ini menggunakan metoda eksperimen yang disusun dalam Rancangan Acak Lengkap (RAL) dengan 5 perlakuan dan 4 ulangan untuk masing-masing perlakuan. Adapun perlakuan yang diberikan adalah A. tanpa POC, B. POC $10 \%$, C. POC $20 \%$, D. POC $30 \%$, dan D. POC $40 \%$. Data dianalisis secara deskriptif.

\section{Cara Kerja}

1. Persiapan Media Tanam

Tanah dikoleksi sebanyak $\pm 1 \mathrm{~m}^{3}$ dari lahan bekas tambang batu kapur PT Semen Padang, Kelurahan Indarung, Kecamatan Lubuk Kilangan, Kotamadya Padang. Setelah itu diayak dan dimasukkan kedalam polybag ukuran $1 \mathrm{~kg}$ untuk dijadikan media tanam.

2. Penyediaan Bioaktivator

Mikroorganisme Indigenous

300g nasi beras diletakkan kedalam wadah kemudian ditutup menggunakan kertas koran, plastik yang sudah dilubangi dan terakhir dilapisi dengan kawat kasa. Setelah itu tanam didalam tanah. Biarkan selama 210 hari agar nasi tersebut dikontaminasi oleh mikroba. Setelah 2-10 hari, dikeluarkan wadah berisi nasi tersebut dari dalam tanah dan tambahkan gula merah (molase) sebanyak 1/3 dari bagian nasi yang digunakan ke wadah yang berisi nasi tersebut. Lalu,ditutup lagi menggunakan kertas dan diikat rapat, ditempatkan pada tempat terlindung selama 1 minggu. Dan jika akan dipakai perlu ditambahkan air 
Jurnal Biologi Universitas Andalas (J. Bio. UA.)

6(1) - Februari 2018: 6-14 (ISSN : 2303-2162)

sebanyak 20 kali lebih banyak, dan disaring menjadi cairan yang mengandung mikroba.

3. Pembuatan Pupuk Organik Cair dengan Bioaktivator Mikroorganisme Indigenous

Sampah sayuran dan buahan dimasukkan kedalam ember plastik besar yang memiliki kran pada bagian bawahnya Kemudian ditambahkan mikrooganisme indigenous nasi yang sudah disiapkan sebagai bioaktivator. Setelah itu ember plastik ditutup rapat dan diamkan selama 2-4 minggu. Saat POC mikroorganisme indigenous akan diaplikasikan ketanaman, POC mikroorganisme indigenous tersebut ditambahkan dengan air sesuai konsentrasi yang dibutuhkan pada perlakuan.

\section{Penanaman Desmodium heterophyllum} ke Media Perlakuan

Tanaman D. heterophyllum didapatkan disekitar HPPB UNAND dengan cara metoda stek batang (vegetatif) yaitu sepanjang 3-5 cm. Kemudian ditanam ke media perlakuan yang telah dipersiapkan. Penanaman dilakukan secara acak sesuai dengan metode yang digunakan.

5. Pemberian Pupuk Organik Cair Mikroorganisme Indigenous

Pemberian pupuk cair mikrooganisme indigenous dilakukan dengan cara melarutkan pupuk organik cair mikrooganisme indigenous kedalam air, sesuai dengan konsentrasi perlakuan yang dilakukan. Kemudian disemprotkan ke bagian tumbuhan $D$. heterophyllum pada media perlakuan. Pemberian pupuk organik cair mikrooganisme indigenous ini dilakukan satu kali seminggu semalam 8 minggu pengamatan.

\section{Parameter Pengamatan}

1. Pertambahan Jumlah Daun

Pengamatan dilakukan setiap satu kali seminggu mulai awal penanaman hingga 8 minggu pengamatan. Daun yang muncul selama pengamatan ditandai sehingga tidak terjadi pengulangan saat penghitungan.

\section{Luasan Tutupan Lahan}

Pengukuran luasan tutupan tanah dilakukan setiap satu kali dalam dua minggu selama 8 minggu pengamatan. Pengukuran dilakukan dengan bantuan kawat yang berukuran 50 $\mathrm{cm}$ x $50 \mathrm{~cm}$. Setiap kawat yang digunakan memiliki lubang-lubang kecil yang berukuran $1 \mathrm{~cm} \quad \mathrm{x} \quad 1 \mathrm{~cm}$ (Gambar 1). Lubang-lubang kecil tersebut untuk mewakili jumlah yang tertutupi oleh tanaman. Semua bagian tanaman yang memasuki lubang kecil tersebut dihitung. Salah satu model yang dapat dipakai untuk menghitung luas tutupan lahan tersebut yang dimodifikasi dari metoda grid line intersection (Brundrett et al., 1996) yaitu sebagai berikut :

Luasan Tutupan Lahan $=\frac{a}{b} \times 100 \%$

Keterangan :

a : Jumlah kotak yang ditutupi tanaman $D$. heterophyllum

b : Jumlah kotak keseluruhan

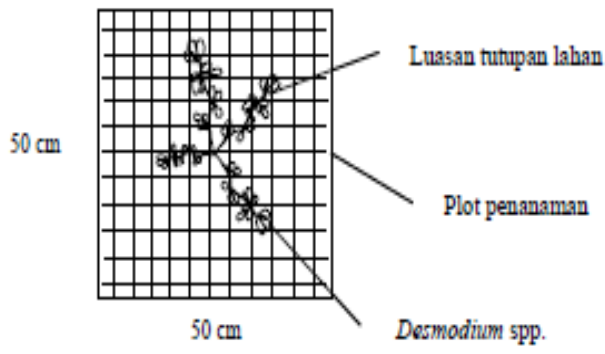

Gambar 1. Cara Perhitungan Luas Penutupan Lahan (Hasanah et al., 2013)

3. Berat basah dan berat kering tanaman Pengamatan berat basah tanaman dilakukan pada akhir pengamatan. Tanaman dicabut dari media tanam. Kemudian dihitung berat basah, bagian yang ditimbang yaitu bagian atas (batang dan daun). Kemudian dilanjutkan dengan pengamatan berat kering tanaman yang dilakukan pada akhir pengamatan. Sebelum ditimbang, tanaman dicuci dengan air mengalir. Kemudian tanaman dibungkus dengan koran, lalu dilakukan pemanasan dengan oven pada suhu $70-80^{\circ} \mathrm{C}$ selama 24 hingga 48 jam, setelah itu ditimbang sampai didapat berat konstan. 


\section{Hasil dan Pembahasan}

\section{Pertambahan Jumlah Daun}

Data parameter pertambahan jumlah daun Desmodium heterophyllum selama 8 minggu pengamatan dapat dilihat pada Gambar 2.

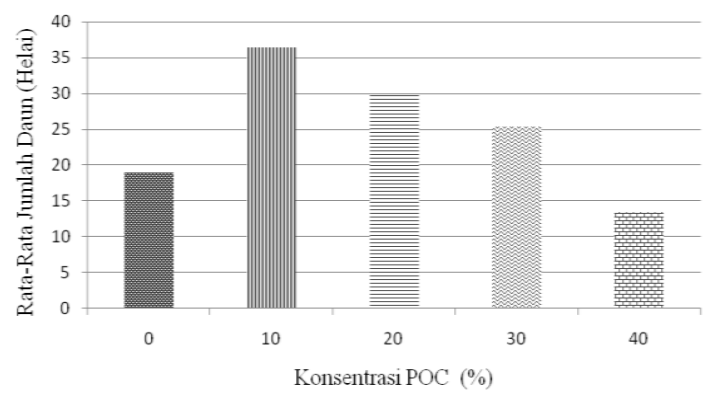

Gambar 2. Rata-Rata Jumlah Daun Desmodium heterophyllum Pada Tanah Bekas Tambang Batu Kapur PT. Semen Padang Dengan Pemberian Pupuk Organik Cair (POC) dengan Bioaktivator Mikroorganisme Indigenous Dari HPPB Selama 8 Minggu Pengamatan

Berdasarkan data yang disajikan pada Gambar 2., dapat dilihat bahwa dengan pemberian konsentrasi POC yang bervariasi memberikan hasil yang berbeda terhadap jumlah daun $D$. heterophyllum. Pada penelitian ini pemberian konsentrasi POC $10 \%$ memberikan hasil yang paling tinggi terhadap jumlah daun $D$. heterophyllum dibandingkan dengan konsentrasi POC lainnya. Hal ini diduga karena unsur hara yang terkandung didalam POC dengan konsentrasi $10 \%$ merupakan unsur hara yang optimum untuk pertumbuhan tanaman $D$. heterophyllum, sehingga dengan peningkatan konsentrasi POC yang diberikan justru cenderung menurunkan rata-rata jumlah daun tanaman D. heterophyllum. Salisbury dan Ross (1995) mengemukakan bahwa tanaman mempunyai mekanisme kontrol terhadap pemakaian POC dari luar, apabila dosisnya telah optimum, zat pengatur ini tidak lagi memicu pertumbuhan tanaman.

Pada umumnya dalam tahap pertumbuhannya tanaman membutuhkan unsur nitrogen $(\mathrm{N})$ dan fosfor $(\mathrm{P})$ pada jumlah tertentu. Hasil uji analisis beberapa unsur hara makro yang terkandung didalam pupuk organik cair yang digunakan yaitu nitrogen $(\mathrm{N})$ 0,77\% dan posfor $(\mathrm{P}) 0,63 \%$. Sesuai dengan Salisbury dan Ross (1995) unsur nitrogen berfungsi untuk sintesa asam amino serta pembentukan protein dalam tanaman. Hardjowigeno (2003) menambahkan bahwa nitrogen sangat dibutuhkan untuk pembentukan dan pertumbuhan bagian-bagian vegetatif tanaman seperti daun, batang dan akar. Sedangkan unsur fosfor dapat membantu meningkatkan pertumbuhan tanaman, memproduksi klorofil, meningkatkan kadar protein dan mempercepat pertumbuhan daun, (Mulyono, 2014). Unsur fosfor juga berperan dalam memicu pertumbuhan akar sehingga dapat menyerap unsur hara dengan baik (Setyamidjaya, 1986).

Pengaruh pemberian pupuk organik cair dengan bioaktivator mikroorganisme indigenous HPPB terhadap pertambahan jumlah daun tanaman $D$. heterophyllum dalam waktu pengamatan satu kali seminggu yang diamati selama 8 minggu pengamatan dapat dilihat pada Gambar 3 .

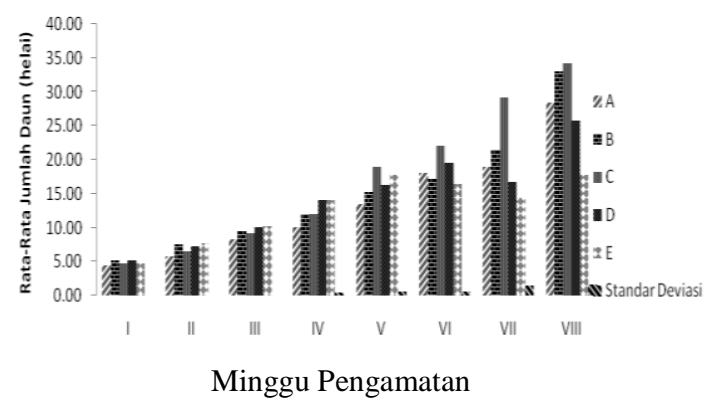

Gambar 3. Rata-Rata Jumlah Daun Desmodium heterophyllum dengan Pemberian Beberapa Konsentrasi Pupuk Organik Cair dengan Bioaktivator Mikroorganisme Indigenous. Keterangan : A. $0 \%$ POC, B. $10 \%$ POC, C. 20 $\%$ POC, D. $30 \%$ POC, dan E. $40 \%$ POC

Berdasarkan Gambar 3., dapat dilihat bahwa pada umumnya terjadi peningkatan jumlah daun setiap minggunya. Namun, ada beberapa perlakuan (D-E) yang mengalami penurunan jumlah daun pada minggu VI ke minggu VII. Hal ini diduga karena terjadinya pengguguran pada daun tanaman $D$ heterophyllum. Meskipun pada setiap perlakuan mengalami pengguguran daun, namun tidak menyebabkan penurunan 
terhadap rata-rata jumlah daun tanaman tersebut. Hal ini sesuai dengan pernyataan Gardner et al., (1991) bahwa daun sebelah bawah suatu tanaman ukurannya lebih kecil dan seringkali gugur karena tekanan lingkungan dan penuaan daun. Proses gugurnya daun ini merupakan salah satu cara tanaman untuk beradaptasi dengan media dan lingkungannya.

Hal ini dibenarkan oleh Arafat (2015) yang telah melakukan penelitian terhadap tanaman D.heterophyllum dan mendapatkan salah satu keunikan dari tanaman tersebut yaitu dimana ketika daun tua tertutupi oleh daun muda, daun tua akan gugur namun hal ini tidak mengganggu pertumbuhan dari $D$. heterophyllum.

\section{Persentase Luas Tutupan Lahan}

Berdasarkan hasil perhitungan luasan tutupan lahan dengan menggunakan rumus modifikasi dari metoda grid line intersection (Brundrett et al., 1996), dapat dilihat secara deskriptif bahwa aplikasi pupuk organik cair (POC) dengan bioaktivator mikroorganisme indigenous dari HPPB, data dapat dilihat pada Gambar 4.

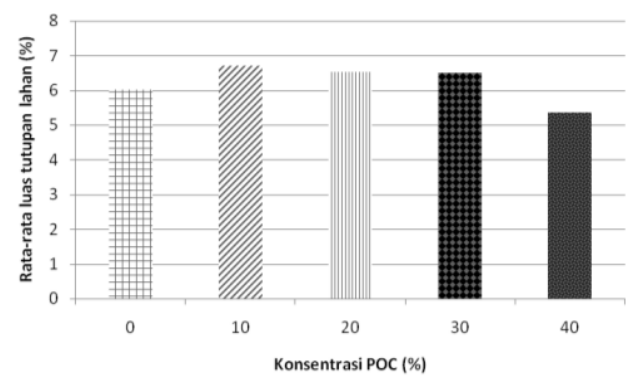

Gambar 4. Rata-rata Persentase Luasan Tutupan Lahan Oleh Desmodium heterophyllum Pada Tanah Bekas Tambang Batu Kapur PT. Semen Padang Dengan Pemberian Pupuk Organik Cair (POC) Dengan Biaktivator Mikroorganisme Indigenous Dari HPPB Setelah 8 Minggu Pengamatan

Berdasarkan data yang disajikan pada Gambar 4., dapat dilihat bahwa dengan pemberian konsentrasi POC yang berbeda memberikan hasil yang berbeda terhadap luas tutupan lahan oleh tanaman D. heterophyllum. Pada penelitian ini pemberian konsentrasi POC $10 \%$ memberikan hasil terbaik baik terhadap luasan tutupan lahan oleh tanaman $D$. heterophyllum dibandingkan dengan konsetrasi POC lainnya. Hal ini diduga karena unsur hara yang terdapat pada POC konsentrasi $10 \%$ merupakan unsur hara optimum yang mampu mendukung pertumbuhan tanaman $D$. heterophyllum tersebut. Namun menurunnya nilai persentase luasan tutupan lahan dengan pemberian dosis konsentrasi pupuk organik cair dengan biaoktivator mikroorganisme indiogenous HPPB dengan konsentrasi 20$40 \%$ diduga karena dosis POC yang tidak cocok untuk menunjang pertumbuhan tanaman.

Sarief (1968) menyatakan bahwa pemberian pupuk harus disesuaikan dengan kebutuhan tanaman. Sebab jika diberikan dalam jumlah yang berlebihan merupakan pemborosan dan bahkan dapat menyebabkan keracunan dan kematian pada tanaman. Salisbury dan Ross (1995) menambahkan bahwa tanaman mempunyai mekanisme kontrol terhadap pemakaian POC dari luar, apabila dosisnya telah optimum, zat pengatur ini tidak lagi memicu pertumbuhan tanaman. Pada penelitian ini dengan POC konsentrasi 10\% diduga merupakan konsentrasi optimum dalam membantu meningkatkan persentase luasan tutupan lahan dari tanaman $D$. heterophyllum.

Penelitian tentang penggunaan $D$. heterophyllum dalam upaya mereklamasi lahan bekas tambang telah dilakukan Arafat (2015), dimana didapatkan hasil bahwa dengan menambahkan tanah dan kompos $(1: 2)$ luas tutupan yang mampu dicapai oleh tanaman D. heterophyllum mencapai 15.4 $\mathrm{cm}$. Hal ini diduga karena komposisi unsur hara yang terkandung didalam pupuk kompos yang digunakan mampu menunjang pertumbuhan $D$. heterophyllum dilahan bekas tambang silika.

Hasanah et al., (2014) juga telah melakukan penelitian tentang upaya reklamasi lahan bekas tambang menggunakan tanaman Desmodium spp., mendapatkan hasil bahwa $D$. heterophyllum dalam nilai luasan tutupan lahannya 
mencapai $100 \%$ dengan kecepatan luasan tutupan lahan $33,15 \mathrm{~cm}^{2} /$ hari pada 8 minggu setelah tanam (MST). Hal ini berbeda dengan hasil yang didapatkan pada penelitian ini, diduga karena pada adanya perbedaan media dan perlakuan yang digunakan pada masing-masing penelitian yang telah dilakukan. Pada penelitian Hasanah et al., (2014) tanah bekas tambang yang digunakan diberikan pupuk kompos, subsoil dan kokopit. Sedangkan pada penelitian ini hanya digunakan media berupa tanah bekas lahan tambang batu kapur yang miskin akan unsur hara. Asmarahman (2008) juga menyatakan bahwa lahan yang telah mengalami aktivitas penambangan batu kapur akan mengakibatkan rendahnya kesuburan lahan akibat miskin hara dan $\mathrm{pH}$ yang tinggi. Selain itu hal ini juga dikarenakan unsur hara yang terkandung didalam pupuk organik cair tidak mampu memenuhi kebutuhan dari $D$. heterophyllum untuk tumbuh dilahan yang miskin hara. Sarief (1986) juga menyatakan bahwa proses pemanjangan sel, pembelahan dan diferensiasi sel akan berjalan baik apabila unsur hara yang tersedia mampu mencukupi kebutuhan dari tanaman tersebut.

Pada Gambar 2 dapat dilihat pengaruh pemberian pupuk organik cair dengan bioaktivator mikroorganisme indigenous HPPB terhadap persentase luasan tutupan lahan oleh tanaman $D$. heterophyllum yang diamati satu kali dua minggu selama 8 minggu pengamatan. Dapat dilihat pada Gambar 5 yaitu terjadinya peningkatan persentase luasan tutupan lahan pada setiap minggu pengamatan

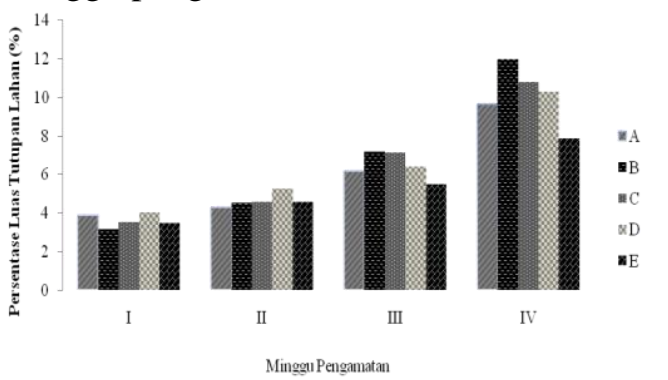

Gambar 5. Grafik Rata-Rata Persentase Luasan Tutupan Lahan Desmodium heterophyllum dengan Pemberian Beberapa Konsentrasi Pupuk
Organik Cair dengan Bioaktivator Mikroorganisme Indigenous. Keterangan : A. 0 $\%$ POC, B. $10 \%$ POC, C. $20 \%$ POC, D. $30 \%$ POC, E. $40 \%$ POC.

Media tanam yang digunakan diduga menjadi salah satu faktor yang mendukung ataupun menghambat pertumbuhan suatu tanaman. Berdasarkan pernyataan Asir, Narendra, Multikaningsih, Summung dan Tabba (2003) tentang pertumbuhan tanaman yang ditanam dilahan bekas tambang batu kapur yaitu pada umumnya tanaman tersebut akan mengalami perlambatan dalam pertumbuhannya dan pada fase tertentu akan mengalami penghentian pertumbuhan yang ditandai dengan keadaan tanaman tetap seperti kondisi awal (awal penanaman).

\section{Berat Basah dan Berat Kering Tanaman}

Dari pengamatan yang telah dilakukan terhadap aplikasi pupuk organik cair (POC) dengan bioaktivator mikroorganisme indigenous dari HPPB terhadap berat basah dan berat kering tanaman Desmodium heterophyllum selama 8 minggu pengamatan didapatkan hasil rata-rata berat basah dan berat kering yang bervariasi pada masing-masing perlakuan yang diberikan. Data rata-rata berat basah dan berat kering tanaman $D$. heterophyllum dapat dilihat pada Gambar 6.

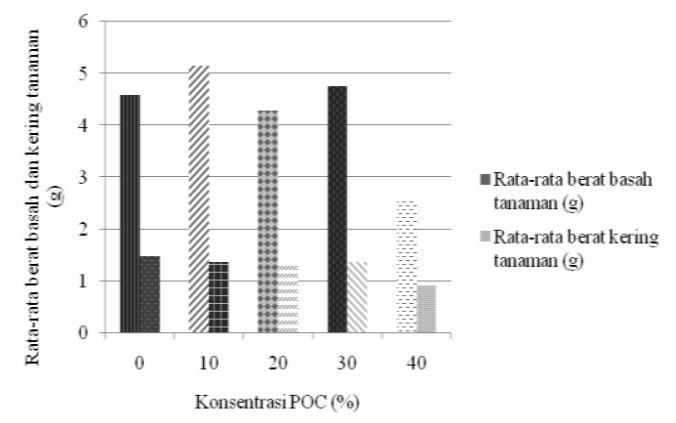

Gambar 6. Rata-Rata Berat Basah Dan Berat Kering Desmodium heterophyllum Pada Tanah Bekas Tambang Batu Kapur PT. Semen Padang Dengan Pemberian Pupuk Organik Cair (POC) Dengan Biaktivator Mikroorganisme Indigenous Dari HPPB Setelah 8 Minggu Pengamatan 
Berdasarkan data yang disajikan pada Gambar 6., pemberian konsentrasi POC yang berbeda memberikan hasil yang bervariasi terhadap berat basah dan berat kering tanaman $D$. heterophyllum. Pada penelitian ini pemberian konsentrasi POC $10 \%$ memberikan hasil yang paling tinggi terhadap berat basah dari tanaman $D$. heterophyllum dibandingkan dengan konsetrasi POC lainnya. Sedangkan untuk parameter berat kering tanpa pemberian POC justru memberikan hasil yang lebih tinggi. Hal ini diduga karena unsur hara yang terdapat pada POC tidak mampu menunjang akumulasi bahan organik sehingga menghambat proses metabolisme yang berhubungan dengan berat kering. Kondisi ini didukung oleh pendapat Lakitan (2004) dalam Bustami, Sufardi dan Bakhtiar (2011) yang menyatakan bahwa berat kering tanaman mencerminkan akumulasi senyawa-senyawa organik yang merupakan hasil sintesa tanaman dari senyawa anorganik yang berasal dari air dan karbondioksida sehingga memberikan kontribusi terhadap berat kering tanaman.

$$
\text { Salisbury dan Ross (1995) }
$$

menambahkan bahwa berat kering merupakan tolak ukur yang menujukkan efisiensi proses fotosintesis pada suatu tanaman. Hasil berat kering merupakan keseimbangan antara fotosintesis dan respirasi. Menurut Gardner et al., (1991) fotosintesis mengakibatkan peningkatan berat kering tanaman karena pengambilan $\mathrm{CO}_{2}$ sedangkan respirasi mengakibatkan penurunan berat kering karena pengeluaran $\mathrm{CO}_{2}$.

Prawiranata, Harran dan Tjondronegoro (1998) menyatakan bahwa berat basah tanaman mencerminkan kadar air dari jaringan tanaman. Menurut Salisbury dan Ross (1995) berat basah tanaman dapat menunjukkan aktivitas metabolisme tanaman dan nilai berat basah tanaman dipengaruhi oleh kandungan air jaringan, unsur hara dan hasil metabolisme. Menurut Sarief (1986) bahwa kandungan air didalam tanaman akan meningkat sejalan dengan peningkatan kandungan nitrogen sehingga dapat meningkatkan bobot berat basah suatu tanaman.

\section{Kesimpulan}

Konsentrasi $0-40 \%$ pupuk organik cair dengan bioaktivator mikroorganisme indigenous dari HPPB terhadap pertumbuhan Desmodium heterophyllum pada tanah bekas tambang batu kapur PT. Semen Padang mampu meningkatkan jumlah daun, persentase luas tutupan lahan dan berat basah tanaman $D$. heterophyllum.

$$
\text { Konsentrasi } 10 \% \text { merupakan }
$$

konsentrasi terbaik dikarenakan mampu meningkatkan jumlah daun, persentase luas tutupan lahan dan berat basah tanaman $D$. heterophyllum pada tanah bekas tambang batu kapur PT. Semen Padang.

\section{Ucapan Terimakasih}

Kami ucapkan terima kasih sebesarbesarnya kepada pihak yang telah membantu dalam penelitian ini; Dr. Nasril Nasir, Dr. Tesri Maideliza dan Prof. Dr. Erizal Mukhtar. Pihak Pertambangan PT. Semen Padang, Pembibitan dan Penghijauan Universitas Andalas yang membantu dalam kelancaran penelitian ini.

\section{Daftar Pustaka}

Arafat, I. N. 2015. Pertumbuhan Desmodium heterophyllum (Willd.) DC. Sebagai Tanaman Penutup Tanah Di Lahan Bekas Tambang Silika. [Skripsi]. Fakultas Kehutanan. Institut Pertanian Bogor. Bogor.

Ardanari, C.Y. 2011. Status Penggunaan FMA Pada Tanaman Fast Growing Species Dalam Pembangunan Hutan Tanaman Industri dan Rehabilitasi Lahan Kritis.[Skripsi].Kehutanan Institut Pertanian Bogor.Bogor.

Ardiansyah, N. 2013. Penampilan Beberapa Jenis Leguminosa Yang Ditanam Pada Lahan Bekas Tambang 
Batubara Dengan Perbaikan Bahan Organik Tanah. [Tesis]. Pasca Sarjana Fakultas Peternakan dan Pertanian Universitas Diponegoro. Semarang.

Ardika, B. D. 2013. Uji Efektivitas Penambahan Cocopeat Terhadap Pertumbuhan Legum Sebagai Tanaman Penutup Di Area Reklamasi Bekas Tambang Batu Bara. Program Studi Biologi. Fakultas Teknobiologi. Universitas Atma Jaya Yogyakarta. Yogyakarta.

Asir. L. D., Narendra, B. H., Multikaningsih, E., Summung, Tabba. 2003, Teknologi Rehabilitasi Lahan Terdegradasi Bekas Tambang Bahan Galian Industri di Pangkep. Laporan Hasil Penelitian Balai Litbang Teknologi Pengelolaan DAS IBT. Makassar

Asmarahman, C. 2008. Pemanfaatan Mikoriza dan Rhizobium Untuk Meningkatkan Pertumbuhan Semai Kayu Energi Pada Media Tanah Bekas Tambang Semen. Tesis. Sekolah Pascasarjana. Institut Pertanian Bogor. Bogor.

Brundrett, N.,B. Bougher, T. Dell, Grove, N. Malajazuk. 1996. Working With Mycorrhizas In Forestry And Algiculture. Australian Centre for International Agriculture Research (ACIAR). Canberra. Pp. 162-171.

Bustami, Sufardi dan Bakhtiar. 2011. Serapan Hara Dan Efisiensi Pemupukan Phosfat Serta Pertumbuhan Padi Varietas Lokal. Fakultas Pertanian Unsyiah. Banda Aceh.
De Lima, C. L. R., Ezequiel, C. C. M., Luis, C. T., Eloy, A. P., Alvaro, P. S. 2012. Soil Compressibility And Least Limiting Water Range of A Constructed Soil Under Cover Crops After Coal Mining In Southern Brazil. Soil \& Tillage Research. 124 : 190-195.

Dwidjoseputro, D. 1994. Pengantar Fisiologi Tumbuhan. PT Gramedia Pustaka.

Gardner, F. P., Pearce, R. B., Mitchell, R. L. 1991. Fisiologi Tanaman Budidaya (Diterjemahkan oleh: Herawati Susilo). Universitas Indonesia Press. Jakarta.

Hajama, N. 2014. Studi Pemanfaatan Eceng Gondok Sebagai Bahan Pembuatan Pupuk Kompos Dengan Menggunakan Aktivator EM4 Dan MOL Serta Prospek Pengembangannya. Program Studi Teknik Lingkungan. Jurusan Teknik Sipil. Fakultas Teknik. Universitas Hasanuddin. Makassar.

Hardjowigeno, S. 2003. Ilmu Tanah. Akademika Pressindo. Jakarta

Hasanah. I. N., Wasis, B., I. Mansur. 2013. Pengembangan Desmodium spp sebagai Tanaman Penutup Tanah dalam Reklamasi Lahan Pasca Tambang. Jurnal Silvikultur Tropika 1(5) : 7-12. 2014.

Lakitan, B. 2004. Dasar-Dasar Fisiologi Tumbuhan. Jakarta. RajaGrafindo Persada

Mansur, I., Ariani, D. 2013. Pertumbuhan Bibit Samama (Anthocephalus macrophyllus (Roxb.) Havil) Ditanam Bersama Tanaman Penutup Tanah. Jurnal Silvikultur Tropika. Vol. 04 No. 03 
Desember 2013, Hal. 119 - 129. ISSN: 2086-8227

Margarettha. 2009. Eksplorasi Dan Identifikasi Mikoriza Indigen Asal Tanah Bekas Tambang Batubara. Berita Biologi 10 (5). 2011.

Mufhendris. 2005. Kerusakan Lingkungan Perairan Hulu Sungai Batang Arau Akibat Penambangan Bahan Baku Semen Oleh PT. Semen Padang di Sumatera Barat. Tesis. Pascasarjana Ilmu Lingkungan. Universitas Gadjah Mada. Yogyakarta.

Mulyono. 2014. Membuat MOL dan Kompos dari Sampah Rumah Tangga. PT AgroMedia Pustaka. Jakarta.

Okti, F. P. 2008. Identifikasi Penyebab Dasar Kecelakaan Kerja Dngan Metoda Fault Tree Analysis (FTA) Di Unit Produksi IV PT. Semen Padang Sumatera Barat. [Skripsi]. Kesehatan Masyarakat. Universitas Indonesia. Depok.

Parnata, A. 2004. Pupuk Organik Cair Aplikasi dan Manfaatnya, Agromedia:Jakarta.
Salisbury, F dan Cleon W. Ross. 1995. Pengantar Fisiologi Tumbuhan Jilid 1. Terjemahan Lukman dan Sumaryono. ITB. Bandung

Sarief, S. 1986. Ilmu Tanah Pertanian. Pustaka Buana. Bandung.

Setyamidjaya, D. 1986. Pupuk dan Pemupukan. Medyatama Sarana Perkasa. Jakarta.

Sitompul, S.M. dan B. Guritno. 1995. Analisis Pertumbuhan Tanaman. Gajah Mada University Press. Yogyakarta. 412 hal.

Sutriadi. M.T. 2007. Pengaruh Pupuk Organik Cair Pada Pertumbuhan dan Hasil Caisim (Brassica rapa convar) Di Incestisols. Balai Penelitian Tanah. Bogor.

Wulandari, U.F. 2011. Penapisan Bakteri Penghasil Antibiotika Dan Pengujian Aktivitas Antibiotiknya. Jurusan Biologi. Fakultas Matematika dan Ilmu Pengetahuan Alam. Universitas Andalas. Padang. 